\title{
PERBANDINGAN KEAKURATAN HASIL PERAMALAN PRODUKSI BAWANG MERAH METODE HOLT-WINTERS DENGAN SINGULAR SPECTRUM ANALYSIS (SSA)
}

\author{
Yogo Aryo Jatmiko', Rini Luciani Rahayu², Gumgum Darmawan ${ }^{3}$ \\ Prodi Magister Statistika Terapan, Universitas Padjajaran, Bandung ${ }^{1,2,3}$ \\ yj29289@gmail.com ${ }^{1}$, al.ashry1211@gmail.com ${ }^{2}$, gumstat@ gmail.com ${ }^{3}$
}

\begin{abstract}
Abstrak
Metode Holt-Winters digunakan untuk memodelkan data dengan pola musiman, baik mengandung trend maupun tidak. Terdapat dua metode peramalan dalam Singular Spectrum Analysis (SSA), yaitu metode rekuren ( $R$-forecasting) dan metode vektor ( $V$-forecasting). Metode rekuren melakukan kontinuasi secara langsung (dengan bantuan LRF), sedangkan metode vektor berhubungan dengan L-continuation. Perbedaan metode tentunya memberikan perbedaan dalam keakuratan hasil ramalan. Untuk melihat perbedaan antara ketiga metode tersebut dilakukan dengan melihat perbandingan keakuratan dan keandalan hasil ramalan. Untuk mengukur ketepatan peramalan digunakan Mean Absolute Percentage Error (MAPE) dan untuk mengukur keandalan hasil peramalan dilakukan dengan tracking signal. Aplikasi dilakukan pada produksi bawang merah Indonesia periode Januari 2006-Desember 2015. Peramalan kedua metode di SSA menggunakan window length $\mathrm{L}=39$ dan grouping $\mathrm{r}=8$. Dengan nilai $\alpha=0.1, \beta=0.001$ dan $\gamma=0.5$, metode HoltWinters additive memberikan hasil yang lebih baik dengan MAPE 13,469\% dibanding metode SSA.
\end{abstract}

Kata kunci: Holt-Winters, MAPE, R-forecasting, SSA, V-forecasting

\begin{abstract}
The Holt-Winters method is used to model data with seasonal patterns, whether trends or not. There are two methods of forecasting in Singular Spectrum Analysis (SSA), namely recurrent method (R-forecasting) and vector method (V-forecasting). The recurrent method performs continuous continuation (with the help of LRF), whereas the vector method corresponds to the Lcontinuation. Different methods of course make a difference in the accuracy of forecast results. To see the difference between the three methods is done by looking at the comparison of accuracy and reliability of forecast results. To measure the accuracy of forecasting used Mean Absolute Percentage Error (MAPE) and to measure the reliability of forecasting results is done by tracking signal. Applications are done on Indonesian red onion production from January 2006 to December 2015. Forecasting of both methods in SSA uses window length $\mathrm{L}=39$ and grouping $r=8$. With $\alpha=0.1, \beta=0.001$ and $\gamma=0.5$, Holt-Winters additive method gives better result with MAPE $13,469 \%$ than SSA method.
\end{abstract}

Keywords: Holt-Winters, MAPE, R-forecasting, SSA, V-forecasting

\section{Pendahuluan}

Bawang merah merupakan salah satu komoditas penting bagi masyarakat Indonesia dan memiliki nilai ekonomis yang cukup tinggi. Selain untuk konsumsi, bawang merah juga merupakan salah satu komoditas ekspor. Bawang merah tidak hanya diekspor dalam bentuk sayuran segar, tetapi juga setelah diolah menjadi produk bawang goreng [1]. Berdasarkan data Food and Agriculture Organization (FAO) tahun 2010-2015, Indonesia menempati urutan keempat sebagai negara eksportir bawang merah di dunia setelah New Zealand, Perancis dan Belanda.

Berdasarkan data SUSENAS Badan Pusat Statistik (BPS), konsumsi bawang merah secara nasional per kapita per tahun pada maret 2015 
sekitar 2,64 kilogram. Sedangkan sebulan sekitar 0,22 kilogram, dan per minggu 52 gram per kapita. Hal tersebut menyebabkan permintaan akan bawang merah terus meningkat seiring dengan perkembangan jumlah penduduk. Data Bappenas menunjukkan permintaan bawang merah pada tahun 2012 mencapai 904 ribu ton mengalami peningkatan pada tahun 2015 menjadi 963,4 ribu ton. Hal ini menyatakan bahwa masyarakat Indonesia tidak terlepas akan kebutuhan bawang merah setiap harinya, dikarenakan bawang merah merupakan penyedap pokok bagi pangan di Indonesia.

Dari keterangan di atas diketahui bahwa bawang merah merupakan komoditas yang penting untuk diteliti perkembangannya. Untuk meneliti perkembangan produksi bawang merah dari waktu ke waktu dapat digunakan metode Holt-Winters dan metode Singular Spectrum Analysis (SSA).

Metode Holt-Winters dapat digunakan untuk data time series yang mengandung trend dan musiman [15]. Metode ini mempunyai dua metode yakni metode perkalian musiman (Multiplicative Seasonal Method) dan metode penambahan musiman (Additive Seasonal Method). Model multiplicative digunakan apabila terdapat kecenderungan atau tanda bahwa pola musiman bergantung pada ukuran data. Dengan kata lain, pola musiman membesar seiring meningkatnya ukuran data. Sedangkan model additive digunakan jika kecenderungan tersebut tidak terjadi.

SSA adalah teknik analisis deret waktu dan peramalan yang menggabungkan unsur analisis klasik time series, multivariate statistics, multivariate geometric, dynamical systems, dan signal processing. Terdapat dua metode peramalan dalam SSA, yaitu metode rekuren ( $R$-forecasting) dan metode vektor ( $V$ forecasting). Metode rekuren adalah metode dasar yang sering digunakan karena relatif lebih mudah [2]. Metode vektor merupakan hasil modifikasi dari metode rekuren. Perbedaan antara $R$-forecasting dan $V$-forecasting adalah peramalan dengan $R$-forecasting melakukan kontinuasi secara langsung (dengan bantuan LRF), sedangkan peramalan dengan $V$ forecasting berhubungan dengan $L$ continuation. Hal ini menyebabkan dalam approximate continuation-nya biasanya memberikan hasil yang berbeda [2][7].

Dengan kelebihan dan kemudahan metode Holt-Winters dan SSA, penulis menggunakan metode peramalan Holt-Winters model additive dan metode $R$-forecasting dan $V$-forecating dalam SSA untuk meramalkan produksi bawang merah, kemudian hasil ketiga metode tersebut akan dibandingkan dengan mengukur ketepatan peramalannya dengan menggunakan MAPE.

\section{Kajian Teori}

\subsection{Metode Holt-Winters}

Metode Holt-Winters ini digunakan untuk mengatasi permasalahan adanya trend dan indikasi musiman [15]. Metode ini merupakan gabungan dari metode Holt dan metode Winters [3]. Titik berat metode ini adalah pada nilai level $(\alpha)$, kemiringan slope $(\beta)$, maupun efek musiman $(\gamma)$. Parameter nilai level $(\alpha)$, kemiringan slope $(\beta)$, maupun efek musiman $(\gamma)$ berada diantara nilai 0 dan 1 . Nilai-nilai yang mendekati 0 berarti bahwa pengaruh pembobot relatif kecil pada nilai pengamatan terbaru ketika membuat perkiraan nilai-nilai masa depan [4]. Peramalan dengan metode ini pada umumnya tidak selalu harus memenuhi kaidahkaidah deret waktu seperti signifikansi autokorelasi dan stasioneritas.

\subsection{Metode Singular Spectrum Analysis (SSA)}

Singular Spectrum Analysis (SSA) dikenal sebagai metode yang powerful untuk analisis deret waktu. SSA adalah teknik analisis deret waktu dan peramalan yang menggabungkan unsur analisis klasik time series, multivariate statistics, multivariate geometric, dynamical systems, dan signal processing [8].

Tujuan utama dari SSA yaitu menguraikan serial aslinya menjadi sejumlah kecil komponen yang dapat diidentifikasi seperti tren, periodik, dan noise, kemudian diikuti oleh rekontruksi dari serial aslinya [5]. SSA merupakan sebuah metode yang sangat berguna untuk memecahkan masalah: (i) menemukan tren dari resolusi yang berbeda; (ii) smoothing; (iii) ekstraksi komponen musiman; (iv) ekstraksi simultan untuk siklus dengan periode kecil dan besar; (v) ekstraksi perioditas dengan amplitudo yang bervariasi; (vi) ekstraksi simultan untuk tren dan perioditas yang kompleks; (vii) mendeteksi change-point [2]. Memecahkan ketujuh masalah tersebut adalah kapabilitas dasar dari SSA. Untuk mencapai kapabilitas 
tersebut, tidak perlu mempertimbangkan model parametrik dari time series.

\section{Metode Penelitian}

\subsection{Metode Holt-Winters Additif}

Model musiman aditif cocok untuk prediksi data time series yang dimana amplitudo atau ketinggian pola musimannya tidak tergantung pada rata-rata level atau ukuran data [6].

Level:

$S_{t}=\alpha\left(Y_{t}-I_{t-L}\right)+(1-\alpha)\left(S_{t-1}+b_{t-1}\right)$

Trend:

$$
b_{t}=\beta\left(S_{t}-S_{t-1}\right)+(1-\beta) b_{t-1}
$$

Seasonal:

Forecast:

$$
I_{t}=\gamma\left(Y_{t}-S_{t}\right)+(1-\gamma) I_{t-L}
$$

\subsection{Algoritma SSA}

$$
F_{t+m}=S_{t}+b_{t} m+I_{t-L+m}
$$

\subsubsection{Dekomposisi}

Pada dekomposisi terdapat dua tahap yaitu Embedding dan Singular Value Decomposition (SVD). Parameter yang memiliki peran penting dalam dekomposisi adalah Window Length (L) [11].

\section{a. Embedding}

Langkah pertama dalam SSA adalah embedding, dimana data deret waktu $F=$ $\left(f_{0}, f_{1}, \ldots, f_{N-1}\right)$ dengan panjang $\mathrm{N}$ dan tidak terdapat data missing ditransformasi ke dalam matriks lintasan berukuran $L x K$. Matriks Lintasan ini merupakan matriks dimana semua elemen pada anti diagonalnya bernilai sama.

$$
X_{i j}=\left[\begin{array}{cccc}
f_{0} & f_{1} & \cdots & f_{K-1} \\
f_{1} & f_{2} & \cdots & f_{K} \\
\vdots & \vdots & \ddots & \vdots \\
f_{L-1} & f_{L} & \cdots & f_{N-1}
\end{array}\right]
$$

Pada tahap ini diperlukan penentuan parameter window length dengan syarat $2<$ $L<\frac{N}{2}$. Dalam penentuan window length ini harus dipertimbangkan kemungkinan bahwa data memiliki komponen periodik. Sampai saat ini penentuan window length masih dengan cara trial and error.

Konsep dasar pada tahap embedding ini adalah melakukan pemetaan yang mentransfer data deret waktu F satu dimensi ke dalam multi dimensi $\mathbf{X}_{1}, \mathbf{X}_{2}, \ldots, \mathbf{X}_{K}$ sehingga didapatkan output sebuah matriks yaitu matriks Hankel dimana semua elemen pada anti diagonalnya bernilai sama.

\section{b. Singular Value Decomposition (SVD)}

Langkah kedua dalam dekomposisi adalah membuat Singular Value Decomposition (SVD) dari matriks lintasan. Misalkan $\lambda_{1}, \ldots, \lambda_{L}$ adalah eigenvalue dari matriks $\mathbf{S}$ dimana $\mathbf{S}=\mathrm{XX}^{\mathrm{T}}$ dengan urutan menurut $\lambda_{1} \geq \cdots \geq \lambda_{L} \geq 0$ dan $U_{1}, \ldots, U_{L}$ adalah eigenvector dari masingmasing eigenvalue. Rank dari matriks $\mathbf{X}$ dapat ditunjukkan dengan $\mathrm{d}=\max \left\{i, \lambda_{i}>0\right\}$. Jika dinotasikan $\boldsymbol{V}_{\boldsymbol{i}}=\frac{\boldsymbol{X}^{T} \boldsymbol{U}_{\boldsymbol{i}}}{\sqrt{\lambda_{\boldsymbol{i}}}}$ untuk i $=1, \ldots, \mathrm{d}$, maka SVD dari matriks lintasan adalah sebagai berikut:

$$
\begin{gathered}
\mathbf{X}=\boldsymbol{X}_{\mathbf{1}}+\boldsymbol{X}_{2}+\cdots+\boldsymbol{X}_{\boldsymbol{d}} \\
=U_{1} \sqrt{\lambda_{1}} V_{1}^{T}+U_{2} \sqrt{\lambda_{2}} V_{2}^{T}+\cdots+U_{d} \sqrt{\lambda_{d}} V_{d}^{T} \\
=\sum_{i=1}^{d} U_{i} \sqrt{\lambda_{i}} V_{i}^{T}
\end{gathered}
$$

Matriks $\mathbf{X}$ terbentuk dari eigenvector $U_{i}$, singular value $\sqrt{\lambda_{i}}$ dan komponen utama $V_{i}^{T}$. Ketiga elemen pembentuk SVD ini disebut dengan eigentriple.

Konsep dasar pada tahap ini adalah mendapatkan barisan matriks dari matriks $\mathbf{S}$, dimana pada masing-masing matriks dalam barisan tersebut mengandung eigenvector $U_{i}$, singular value $\sqrt{\lambda_{i}}$ dan komponen utama $V_{i}^{T}$ yang menggambarkan karakteristik pada masing-masing matriks dalam barisan tersebut.

\subsubsection{Rekontruksi}

Dalam tahap rekontruksi terdapat dua langkah yang harus dilakukan, yaitu langkah Grouping kemudian dilanjutkan dengan pembentukan deret rekontruksi berdasarkan hasil yang diperoleh pada langkah diagonal averaging.

\section{a. Grouping}

Pada langkah akan dilakukan pengelompokan hasil dekomposisi matriks lintasan yang berukuran $L x K$ dengan tujuan untuk memisahkan kompononen aditif SVD ke dalam beberapa sub kelompok, yaitu tren, musiman, periodik dan noise. Setelah itu menjumlahkan matriks dalam setiap kelompok. Hasil yang diperoleh berupa representasi dari matriks lintasan sebagai jumlah dari beberapa matriks resultan.

Matriks lintasan $\boldsymbol{X}_{\boldsymbol{i}}$ akan dipartisi ke dalam $\mathrm{m}$ subset disjoin $I_{1}, I_{2}, \ldots, I_{m}$. Misalkan $I=$ 
$\left\{i_{1}, i_{2}, \ldots, i_{p}\right\}$ adalah matriks resultan $\boldsymbol{X}_{\boldsymbol{I}}$ dengan indeks $i_{1}, i_{2}, \ldots, i_{p}$ sesuai dengan kelompok $I$ yang dapat didefiniskan sebagai $\boldsymbol{X}_{\boldsymbol{I}}=\boldsymbol{X}_{\boldsymbol{i} \mathbf{1}}+$ $\boldsymbol{X}_{\boldsymbol{i} \mathbf{2}}+\cdots+\boldsymbol{X}_{\boldsymbol{i} \boldsymbol{p}}$. Kemudian $\boldsymbol{X}_{\boldsymbol{I}}$ disesuaikan dengan kelompok $\boldsymbol{I}=\left\{I_{1}, I_{2}, \ldots, I_{m}\right\}$. Maka, $\mathbf{X}=\boldsymbol{X}_{\mathbf{1}}+\boldsymbol{X}_{\mathbf{2}}+\cdots+\boldsymbol{X}_{\boldsymbol{d}}$ dapat diekspansi menjadi $X=X_{I 1}+X_{I 2}+\cdots+X_{I m}$.

Pada tahap singular value decomposition telah didapatkan eigenvalue yang menggambarkan karakteristik untuk setiap kolom pada matriks $\boldsymbol{S}=X X^{T}$. Eigenvalue ini direpresentasikan oleh eigenvector. Oleh karena itu bahan dasar pengelompokan pada tahap grouping adalah eigenvector. Eigenvector pada masing-masing kolom pada matriks lintasan akan dilakukan ekstraksi terhadap pola komponen seriesnya. Ekstrasi pertama dilakukan terhadap pola tren, kemudian dilakukan ekstraksi dilakukan terhadap pola musiman dengan menggunakan analisis spektral. Eigenvector yang mengikuti pola musiman dengan periode kurang dari 12 maka digolongkan pada kelompok musiman, sedangkan eigenvecktor yang megikuti pola musiman dengan periode lebih dari 12 akan digolongkan pada kelompok siklik. Kemudian eigevector yang tidak mengikuti musiman atau siklik atau tren akan digolongkan sebagai noise [9].

Metode untuk mengekstra tren pada SSA diantaranya dengan menggunakan pendekatan naïve [8][9]. Tujuan dari pendekatan naive ini untuk mengkonstruksi tren dari beberapa komponen awal Singular Value Decomposition. Hal ini dikarenakan eigenvalue merupakan kontribusi dari komponen Singular Value Decomposition yang bersesuaian ke dalam bentuk time series. Tren biasanya mencirikan bentuk time series, dimana eigenvalue dari tren lebih besar dibandingkan dengan yang lainnya, yang berarti bahwa tren adalah komponen dengan nomor urutan yang terkecil.

Dalam mengekstraksi pola musiman digunakan metode analisis spektral. Metode spektral ini dapat digunakan untuk mendeteksi masing-masing eigenvector apakah memiliki pola musiman atau tidak. Jika masing-masing eigenvector memiliki pola musiman kemudian ditentukan perioditas musimannya. Kelompok eigenvector yang memiliki periode yang sama akan dikelompokkan menjadi satu kelompok.

\section{b. Diagonal Averaging}

Setelah melakukan grouping, tahap selanjutnya akan dilakukan transformasi dari hasil pengelompokan $\boldsymbol{X}_{\boldsymbol{I} \boldsymbol{i}}$ ke dalam deret baru dengan panjang N. Tujuan dari tahap ini adalah mendapatkan singular value dari komponenkomponen yang telah dipisahkan, kemudian akan digunakan dalam peramalan. Hasil pada tahap ini merupakan matriks $\mathbf{F}$.

$$
\mathbf{F}=\left[\begin{array}{cccc}
f_{11} & f_{21} & \cdots & f_{K} \\
f_{21} & f_{22} & \cdots & f_{K+1} \\
\vdots & \vdots & \ddots & \vdots \\
f_{L} & f_{L+1} & \cdots & f_{N}
\end{array}\right]
$$

Diagonal average dirumuskan sebagai berikut:

$$
\begin{aligned}
& g_{k}=\left\{\begin{array}{l}
\frac{1}{k} \sum_{m=1}^{k} f_{m, k-m+1}^{*} \quad \text { untuk } 1 \leq k \leq L^{*} \\
\frac{1}{L^{*}-1} \sum_{m=1}^{L^{*}-1} f_{m, k-m+1}^{*} \text { untuk } L^{*}<k \leq K^{*}+1 \\
\frac{1}{N-k+1} \sum_{m=k-K+1}^{N-K^{*}+1} f_{m, k-m+1}^{*}
\end{array}\right. \\
& \text { untuk } K^{*}+1<k \leq N
\end{aligned}
$$

Dimana $\quad L^{*}=\min (L, K) \quad$ dan $\quad K^{*}=$ $\max (L, K)$. Persamaan diatas jika diaplikasikan ke dalam matriks resultan $\boldsymbol{X}_{\boldsymbol{i m}}$ akan membentuk deret $\tilde{Y}^{(k)}=\left(\tilde{y}_{1}^{(k)}, \ldots, \tilde{y}_{N}^{(k)}\right)$. Oleh karena itu, deret asli akan didekomposisi menjadi jumlah dari $\mathrm{m}$ deret.

$$
y_{n}=\sum_{k=1}^{m} \tilde{y}_{n}(k)
$$

\subsection{Peramalan SSA}

Terdapat dua metode peramalan dalam SSA, yaitu metode rekuren ( $R$-forecasting) dan metode vektor ( $V$-forecasting). Metode rekuren adalah metode dasar yang sering digunakan karena relatif lebih mudah [2]. Metode vektor merupakan hasil modifikasi dari metode rekuren. Dalam peramalan SSA, model dibangun dengan bantuan Linear Rekuren Formula (LRF). Bentuk polynomial sebagai berikut:

$$
x_{i+d}=\sum_{k=1}^{d} r_{k} x_{i+d-k}
$$

untuk,

$$
1 \leq i \leq N-d
$$

Perbedaan antara $R$-forecasting dan $V$ forecasting adalah peramalan dengan $R$ forecasting melakukan kontinuasi secara langsung (dengan bantuan LRF), sedangkan peramalan dengan $V$-forecasting berhubungan 
dengan L-continuation. Hal ini menyebabkan dalam approximate continuation-nya biasanya memberikan hasil yang berbeda [2].

Kedua metode peramalan tersebut, memiliki dua tahapan umum yaitu, diagonal averaging dan continuation. Pada metode $R$ forecasting, diagonal averaging digunakan untuk memperoleh rekontrusksi dan continuation dilakukan dengan LRF. Sedangkan pada $V$-forecasting, kedua tahap digunakan dalam urutan kebalik, yaitu peramalan vektor dilakukan terlebih dahulu, kemudian diagonal averaging memberikan nilai ramalan. Untuk mendapatkan M periode ke depan, metode $V$-forecasting menggunakan prosedur M+L-1 langkah. Tujuannya untuk melihat kesesuaian variasi di bawah M langkah, sehingga metode ini memiliki L-1 langkah tambahan.

\section{a. Algoritma Peramalan Metode Rekuren SSA ( $R$-forecasting)}

Algoritma peramalan dengan $R$ forecasting adalah sebagai berikut:

1. Penaksiran koefisien LRF $\left(r_{1}, r_{2}, \ldots, r_{d}\right)$ digunakan eigenvector yang diperoleh dari langkah Singular Value Decomposition. Dengan $P=\left(p_{1}, p_{2}, \ldots, p_{L-1}, p_{L}\right)^{T}, P^{\bar{V}}=$ $\left(p_{1}, p_{2}, \ldots, p_{L-1}\right)^{T}, \pi_{i}$ komponen

terakhir dari vektor $\left(p_{1}, p_{2}, \ldots, p_{L-1}, p_{L}\right)$, dan $v^{2}=\sum_{i=1}^{L-1} \pi_{i}^{2}$ maka koefisien LRF (vektor $\mathrm{R}$ ) dapat dihitung dengan persamaan:

$\Re=\left(r_{l-1}, \ldots, r_{1}\right)=\frac{1}{1-v^{2}} \sum_{i=1}^{L-1} \pi_{i} P_{i}^{\bar{V}}$

2. Dalam metode rekuren ini, deret waktu yang digunakan adalah deret hasil rekontruksi yang diperoleh dari hasil diagonal averaging, kemudian ditentukan $M$ buah titik baru untuk ramalan. Sehingga akan terbentuk deret hasil peramalan, yaitu $G_{N+M}=\left(g_{1}, \ldots, g_{N+M}\right) \quad$ berdasarkan rumus dibawah ini:

$$
g_{i}=\left\{\begin{array}{l}
\tilde{x}_{i} \quad \text { untuk } \mathrm{i}=0, \ldots, \mathrm{N} \\
\sum_{j=1}^{L-1} r_{i} g_{i-1} \text { untuk i }=\mathrm{N}+1, \ldots, \mathrm{N}+\mathrm{M}
\end{array}\right.
$$

Dimana $g_{N+1}, \ldots, g_{N+M}$ adalah hasil ramalan dari SSA.

\section{b. Algoritma Peramalan Metode Vektor SSA (V-forecasting)}

Metode vektor merupakan modifikasi dari metode rekuren. Algoritma peramalannya adalah sebagai berikut:

1. Setelah tahapan SVD pada algoritma awal, matriks lintasan telah membentuk matriks Hankel H, tahap selanjutnya adalah menghitung matriks $\Pi$. Matriks $\boldsymbol{\Pi}$ adalah matriks operator linier dari proyeksi ortogonal $\mathbb{R}^{L-1} \rightarrow \mathcal{L}_{r}^{\nabla}$.

$$
\begin{gathered}
\boldsymbol{\Pi}=\mathbf{v}^{\nabla}\left(\mathbf{v}^{\nabla}\right)^{T}+\left(1-v^{2}\right) \Re \Re^{T} \\
\text { dengan } \mathbf{v}^{\nabla}=\left[P_{1}^{\nabla}, \ldots, P_{r}^{\nabla}\right]
\end{gathered}
$$

2. Hitung operator linier untuk $R$-forecasting

$$
P^{(v)} X=\left[\begin{array}{c}
\Pi X_{\Delta} \\
\mathfrak{R}^{T} X_{\Delta}
\end{array}\right]
$$

$X_{\Delta}$ merupakan vektor yang berisi $\mathrm{L}-1$ komponen akhir dari vektor $\mathrm{X}$

3. Hitung nilai $Z_{i}$

$$
Z_{i}=\left\{\begin{array}{cc}
\hat{X}_{i} & \text { untuk } \mathrm{i}=1, \ldots, \mathrm{K} \\
P^{(v)} Z_{i-1} & \text { untuk } \mathrm{i}=\mathrm{K}+1, \ldots, \mathrm{K}+\mathrm{M}+\mathrm{L}-1
\end{array}\right.
$$

4. Hitung diagonal averaging dari matriks $\mathbf{Z}=\left[\mathbf{Z}_{\mathbf{1}}, \ldots, \mathbf{Z}_{\mathbf{K}+\mathbf{M}+\mathbf{L}-\mathbf{1}}\right] . \quad$ Diagonal averaging yang diperoleh memiliki deret $g_{0}, \ldots, g_{N+M+L-1}$.

5. M nilai baru hasil peramalan metode vektor adalah $g_{N}, \ldots, g_{N+M+1}$.

\subsection{Mean Absolute Percentage Error (MAPE)}

Salah satu ukuran untuk membandingkan akurasi ramalan adalah MAPE, yang dirumuskan sebagai berikut:

$$
\begin{aligned}
M A P E & =\left(\frac{1}{H} \sum_{h=1}^{H}\left|\frac{e_{h}}{Z_{T+h}}\right|\right) \\
& =\left(\frac{1}{H} \sum_{h=1}^{H}\left|\frac{Z_{T+h}-\hat{Z}_{T+h}}{Z_{T+h}}\right|\right) \times 100 \%
\end{aligned}
$$

Dimana:

$\mathrm{H}$ : Banyaknya observasi yang diramalakan (outsample)

T: Banyaknya observasi yang diuji (insample) 


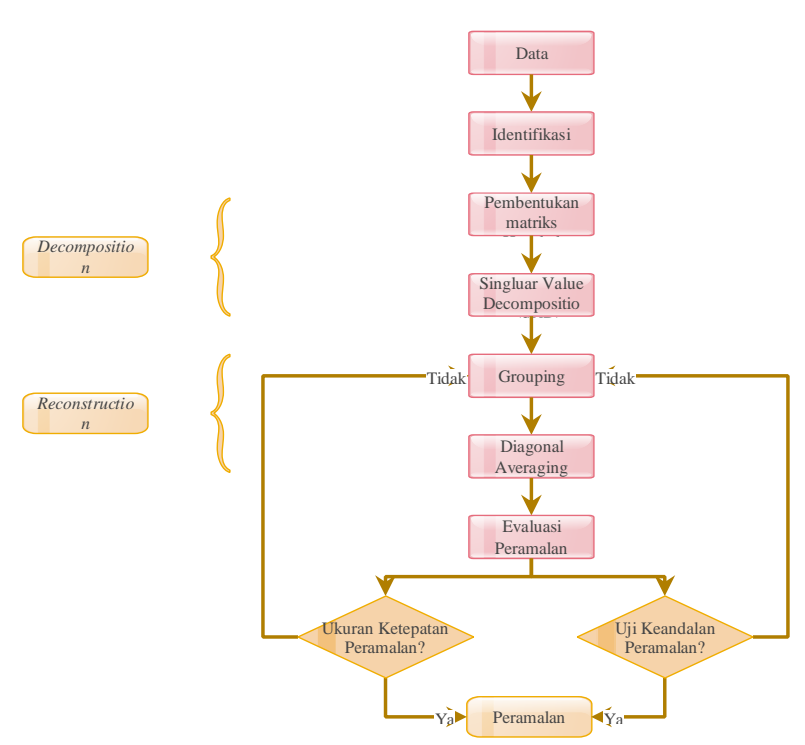

Gambar 1. Skema Prosedur Penelitian
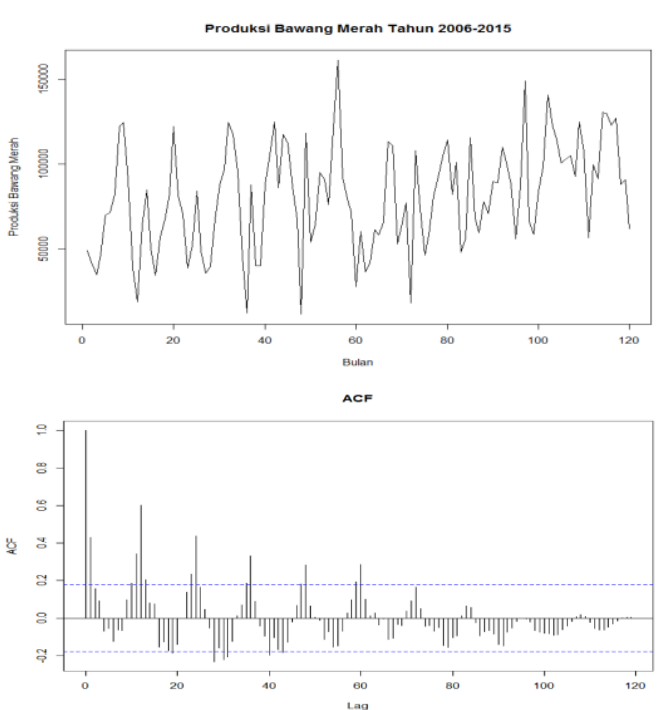

Gambar 2. Plot dan ACF Produksi Bawang Merah Indonesia Januari 2006-Desember 2015

\subsection{Identifikasi Data}

Berdasarkan plot data produksi bawang merah Indonesia dari bulan Januari 2006 hingga Desember 2015, produksi bawang merah di Indonesia memiliki fluktuasi yang tajam [12], [13], [14]. Hal ini terlihat dari turun naiknya produksi bawang merah dengan ekstrim. Pada plot ini pola musiman tidak nampak dengan jelas, namun bila dilihat dari ACFnya nampak jelas bahwa data produksi bawang memiliki pola musiman.

Selain dengan melihat plot dan ACF, identifikasi data musiman dilakukan dengan analisis spektral. Dari hasil perhitungan analisis spektral menunjukkan bahwa data memiliki pola musiman dengan periode 12. Periode inilah yang akan digunakan dalam perhitungan SSA.

Produksi bawang merah Indonesia dengan metode Holt-Winters dan Singular Spectrum Analysis. Pada perhitungannya menggunakan program $\mathrm{R}$ versi 3.3.2. Peramalan dalam SSA dilakukan dalam 2 metode yaitu $R$-forecasting dan $V$-forecasting kemudian ketiga metode tersebut dibandingkan ketepatan dan keandalan peramalannya. Untuk mengukur ketepatan peramalannya digunakan Mean Absolute Percentage Error (MAPE) dan untuk mengukur keandalannya dengan tracking signal.

\subsection{Peramalan Produksi Bawang Merah Indonesia dengan Metode Holt-Winters}

Di dalam metode Holt-Winters terdapat tiga parameter, yaitu level $(\alpha)$, trend $(\beta)$, dan efek musiman $(\gamma)$. Dalam penelitian ini akan digunakan metode Holt-Winters additif. Dengan menggunakan software $\mathrm{R}$ 3.3.2 diperoleh nilai $\alpha$ $=0.1, \quad \beta=0.001$ dan $\gamma=0.5$ yang memiliki MAPE terkecil. Pada Gambar 3 terlihat bahwa nilai fitted dan nilai observed (aktual) hampir mendekati dan mengikuti pola yang sama. Hal ini menunjukkan metode Holt-Winters layak digunakan untuk data produksi bawang merah Indonesia. 


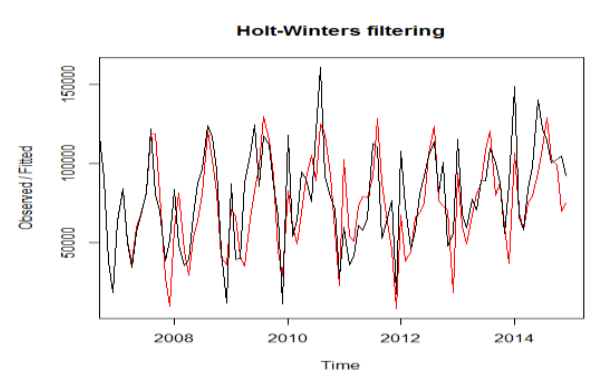

Gambar 3. Holt-Winters Method for Produksi Bawang Merah Indonesia

\subsection{Peramalan Produksi Bawang Merah Indonesia dengan Singular Spectrum Analysis}

Dalam proses Singular Spectrum Analysis terdapat dua langkah, yaitu Dekomposisi dan Rekontruksi. Dekomposisi terdiri Embedding dan Singular Value Decomposition (SVD). Sedangkan tahap Rekontruksi terdiri dari Grouping dan Diagonal Averaging.

Pada proses embedding menentukan nilai window length $(\mathrm{L})$, dengan $2<L<\frac{N}{2}$. Melalui Trial dan Error dilakukan pemilihan nilai L dengan sofware $\mathrm{R}$ dengan nilai MAPE minimum. Nilai $L=39$ memiliki nilai MAPE minimum sehingga diperoleh matriks lintasan yaitu matriks Hankel C berdimensi 39 x 39, seperti berikut :

$$
\begin{gathered}
C_{39 \times 39}=\left[\begin{array}{cccc}
C_{0} & C_{1} & \cdots & C_{38} \\
C_{1} & C_{2} & \cdots & \vdots \\
\vdots & \vdots & \ddots & C_{75} \\
C_{38} & \cdots & C_{75} & C_{76}
\end{array}\right] \\
C_{39 \times 39}=\left[\begin{array}{ccccc}
48884 & 40983 & \cdots & 39997 \\
40983 & 34691 & \cdots & \vdots \\
\vdots & \vdots & \ddots & 104847 \\
39997 & \cdots & 104847 & 92480
\end{array}\right]
\end{gathered}
$$

Selanjutnya mendapat nilai $\mathrm{K}=\mathrm{N}-\mathrm{L}+1$, sehingga pada proses Singular Value Decomposition (SVD) akan membuat matriks dengan ordo LxK. Salah satu unsur pada tahap ini adalah adanya nilai singular value yang merupakan akar kuadrat eigenvalue.

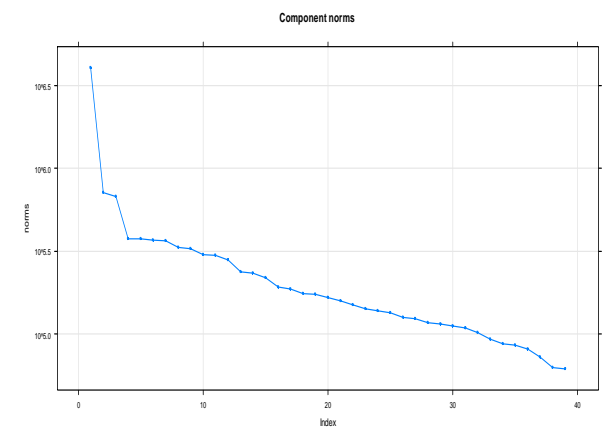

Gambar 4. Plot Eigenvalue

Tahap selanjutnya, yaitu SVD yang akan menghasilkan 39 eigentriple dari matriks $\mathbf{S}=$ $\mathbf{X} \boldsymbol{X}^{\boldsymbol{T}}$. Eigentriple ini terdiri dari singular value, eigenvector, dan principal component. Nilai eigentriple ini digunakan untuk memisahkan komponen, sehingga komponen ini dapat dikelompokan. Hal ini dapat dilihat pada gambar 4.

Berdasarkan gambar 4, dapat diketahui banyaknya grouping, langkah selanjutnya adalah melakukan identifikasi komponenkomponen. Berdasarkan gambar 5, eigenvector pertama memiliki pola tren, eigenvector 2 dan 3 diidentifikasi sebagai pola siklik. Eigenvector 4-21 menunjukkan pola musiman, sedangkan sisanya dianggap noise. Untuk melakukan identifikasi visual komponen periodik, tidak dapat ditentukan hanya dengan melalui plot saja, namun akan dilakukan melalui pengujian musiman dengan analisis spektral.

Dari informasi eigentriple yang terbentuk, dapat disimpulkan bahwa terdapat 8 group yaitu trend, siklis, season1, season2, season3, season 4, dan season 5, serta noise. Untuk melihat keterpisahan komponen-komponen, dapat dilihat pada gambar 5. Dari gambar 6, besarnya korelasi ditunjukkan oleh gradasi warna dari warna muda hingga tua. Semakin tua warnanya semakin tinggi korelasinya. Dari matriks diatas terlihat bahwa tren, siklik dan season 2 tidak berkorelasi dengan komponen lainnya, season 4 dan season 5 menunjukkan adanya korelasi antar komponen, namun korelasi tersebut tidak terlalu dalam. Sehingga, group yang terbentuk dianggap sudah baik. 


\begin{tabular}{ll}
\hline ISSN: 2527-3159 & E-ISSN: 2527-3167 \\
\hline
\end{tabular}

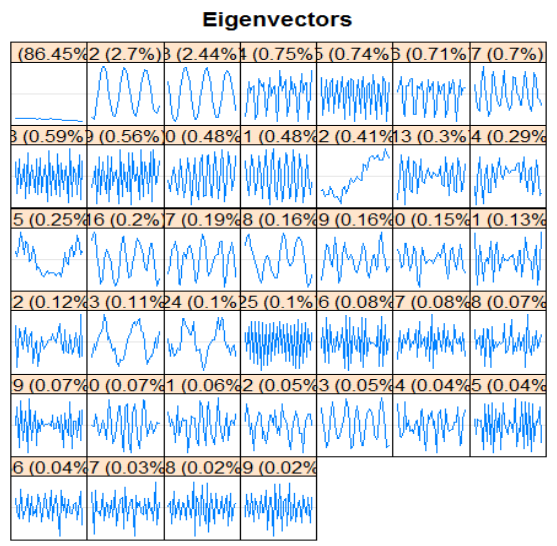

Gambar 5. Eigenvectors

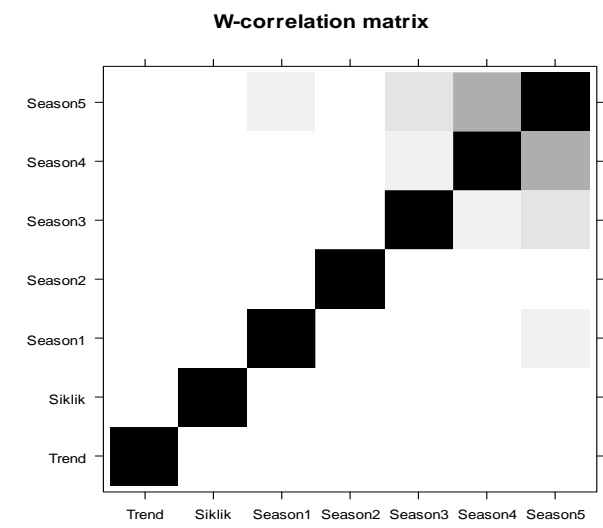

Gambar 6. Matrik W-Correlation

\subsection{Perbandingan Peramalan dengan Metode Holt-Winters, Metode Rekurren SSA dan Metode Vektor SSA}

Gambar 7 menyajikan grafik outsample dan hasil ramalan produksi bawang merah Indonesia untuk 12 bulan ke depan dengan menggunakan metode $R$-forecasting dan $V$ forecasting. Outsample dengan garis hitam, hasil ramalan metode Holt-Winters dengan garis warna hijau, hasil ramalan $R$-forecasting dengan garis merah dan hasil ramalan $V$ forecasting dengan garis biru. Dari gambar tersebut, terlihat bahwa peramalan produksi bawang merah Indonesia untuk 12 bulan ke depan dengan metode Holt-Winters dan metode rekuren ( $R$-forecasting) serta metode vektor ( $V$ forecasting), terdapat sedikit perbedaan. Jika dibandingkan dengan data outsample, hasil ramalan metode Holt-Winters lebih mendekati nilai dari outsample.

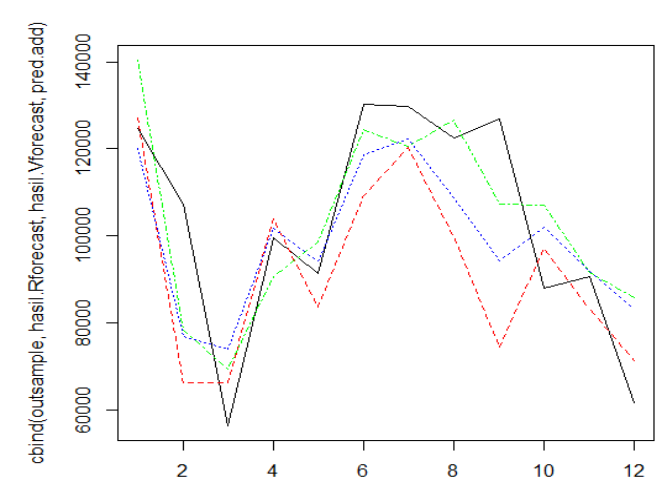

Gambar 7. Outsample, Hasil Ramalan Holt-Winters, $\boldsymbol{R}$-forecasting dan $\boldsymbol{V}$-forecasting

Selanjutnya akan dilihat keakuratan hasil peramalan dengan menggunakan nilai MAPE. Berdasarkan tabel 1, menunjukkan bahwa hasil keakuratan peramalan dari metode Holt-Winters sebesar $13,469 \%$. Sedangkan metode rekuren sebesar $15,625 \%$ dan metode vektor sebesar $14,295 \%$. Kriteria MAPE menurut [10] yaitu, (i) $<10 \%$ peramalan sangat akurat, (ii) $10-20 \%$ peramalan akurat, (iii) $20-50 \%$ peramalan cukup akurat, (iv) $<50 \%$ kurang akurat. Menurut MAPE kriteria Lewis, ketiga metode peramalan tersebut, termasuk ke dalam kategori peramalan akurat. Namun, hasil pengujian menunjukkan metode Holt-Winters memiliki MAPE lebih kecil dibandingkan metode rekuren dan metode vektor. Dengan demikian, peramalan produksi bawang merah Indonesia lebih akurat jika menggunakan metode HoltWinters.

Tabel 1. Keakuratan Hasil Ramalan

\begin{tabular}{|c|c|}
\hline Metode Peramalan & MAPE \\
\hline Rekuren ( $R$-Forecasting) & 15.625 \\
\hline Vektor (V-Forecasting) & 14.295 \\
\hline Holt-Winters & 13.469 \\
\hline \multicolumn{2}{|c|}{$\begin{array}{l}\text { Dari Gambar } 8 \text { menunjukkan tracking } \\
\text { signal hasil peramalan produksi bawang merah } \\
12 \text { bulan terakhir dengan menggunakan metode } \\
\text { Holt-Winters, metode } R \text {-forecasting dan metode } \\
\text { V-forecasting. Besarnya nilai-nilai tracking } \\
\text { signal dari } 12 \text { periode waktu yang diramalkan } \\
\text { berada pada batas toleransi yang bisa diterima } \\
\text { yaitu } \pm 5 \text { (Bovas dan Ledolter, 1983). In }\end{array}$} \\
\hline
\end{tabular}


menunjukkan bahwa metode peramalan masih bisa digunakan untuk meramalkan $\mathrm{M}$ waktu ke depan.

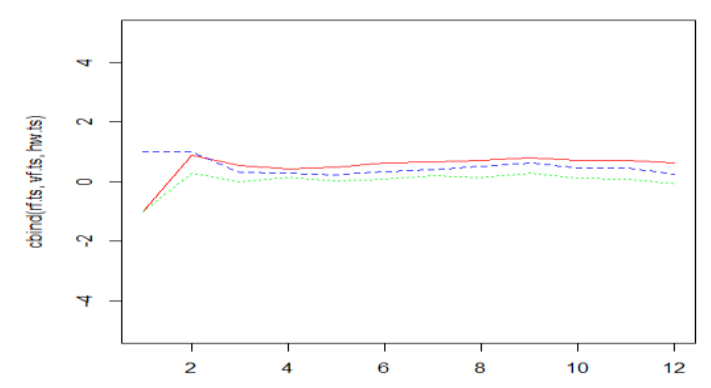

Gambar 8. Tracking Signal Holt-Winters, Rforecasting dan $V$-forecasting

Berdasarkan tabel 2, dengan metode HoltWinters produksi bawang Merah pada tahun 2016 akan mencapai puncaknya pada bulan Januari 2016. Metode tersebut meramalkan bulan Maret 2016 saat bawang merah mengalami produksi terendah dalam setahun. Pada bulan Maret produksi bawang merah mengalami kekurangan sebesar 18 ribu ton. Namun pada bulan Januari mengalami surplus sebesar 53 ribu ton. Selain bulan maret, pada bulan Februari dan Desember juga mengalami kekurangan masing-masing sekitar 9 ribu ton dan 4 ribu ton, namun pada bulan-bulan yang lain mengalami surplus, sehingga kebutuhan bawang merah untuk satu tahun masih bisa terpenuhi.

Tabel 2. Hasil Ramalan Produksi Bawang Merah Tahun 2016 dengan Metode Holt-Winters

\begin{tabular}{lr}
\hline Bulan & $\begin{array}{l}\text { Hasil Ramalan } \\
\text { (dalam ton) }\end{array}$ \\
\hline Januari & 133752.63 \\
Februari & 71609.98 \\
Maret & 62206.55 \\
April & 83141.05 \\
Mei & 91047.23 \\
Juni & 116373.16 \\
Juli & 112312.77 \\
Agustus & 118085.74 \\
September & 98538.70 \\
Oktober & 97892.98 \\
November & 82314.93 \\
Desember & 76112.33 \\
\hline
\end{tabular}

\section{Kesimpulan}

Berdasarkan fenomena data produksi bawang merah Indonesia dapat disimpulkan bahwa data produksi bawang merah Indonesia merupakan data musiman dengan periode 12 . Hasil trial dan error menghasilkan window length $=39$. Hasil MAPE menunjukkan bahwa metode $R$-forecasting dan $V$-forecasting serta Holt-Winters menghasilkan peramalan dengan kategori akurat, namun Holt-Winters lebih akurat dibandingkan $R$-forecasting dan $V$-forecasting. Uji keandalan melalui tracking signal menunjukkan bahwa metode peramalan masih bisa digunakan untuk meramalkan $\mathrm{M}$ waktu ke depan. Produksi bawang Merah pada tahun 2016 akan mencapai puncaknya pada bulan Januari 2016 dan pada bulan Maret 2016 saat bawang merah mengalami produksi terendah dalam setahun. Pada bulan Maret produksi bawang merah mengalami kekurangan sebesar 18 ribu ton, sedangkan pada bulan Januari mengalami surplus sebesar 53 ribu ton. Selain bulan Maret, pada bulan Februari dan Desember juga mengalami kekurangan masing-masing sekitar 9 ribu ton dan 4 ribu ton, namun pada bulan-bulan yang lain mengalami surplus, sehingga kebutuhan bawang merah untuk satu tahun masih bisa terpenuhi.

\section{Referensi}

[1] Latarang, Burhanuddin, dkk. Pertumbuhan Dan Hasil Bawang Merah (Allium Ascalonicum L.) Pada Berbagai Dosis Pupuk Kandang, Journal Agroland 13(3), September (2006) 265-269

[2] Golyandina N., Nekrutkin, V., Zhigljavsky A. Analysis of Time Series Structure: SSA and Related Techniques. Chapman \& Hall/crc (2001)

[3] Croux, C., Gelper, S. \& Fried, R. Computational aspects of robust Holt-Winters smoothing based on M-estimation. Appl Math (2008) 53: 163.

[4] Coghlan, Avril. A Little Book of R For Time Series Release 0.2. Parasite Genomics Group, Wellcome Trust Sanger Institute, Cambridge, U.K. (2017)

[5] Hassani, Hossein. Singular Spectrum Analysis: Methodology and Comparison. Journal of Data Science 5 (2007) 239-257 
[6] Montgomery, D. C, Introduction to Time Series Analysis and Forecasting, 2nd Edition, 2008

[7] Sakinah, A.M.. Perbandingan Stabilitas Hasil Peramalan Suhu dengan R-Forecasting dan $V$-Forecasting SSA untuk Long-Horizon. Tesis. Universitas Padjadjaran, Bandung. 2012.

[8] Golyandina N., Zhigljavsky A.. Singular Spectrum Analysis for Time Series. New York: Springer (2013)

[9] Darmawan, G., Hendrawati T., Arisanti R., Model Auto Singular Spectrum Untuk Meramalkan Kejadian Banjir di Bandung dan Sekitarnya. Prosiding Seminar Nasional Matematika dan Pendidikan Matematika UNY 2015. November (2015) 457-462, Yogyakarta

[10] Amalia, S.N. Peramalan Singular Spectrum Analysis dengan Missing Data. Tesis. Universitas Padjadjaran, Bandung. 2016.

[11] Darmawan, G.Identifikasi Pola Data Curah Hujan Pada Proses Grouping dalam Metode Singular Spectrum Analysis. Prosiding Seminar Nasional Matematika dan Pendidikan Matematika UNY 2016. November (2016) 127-132, Yogyakarta

[12] Kementerian Pertanian. Outlook Bawang Merah 2013. Diambil dari http://epublikasi.setjen.pertanian.go.id/arsipoutlook/260-outlook-komoditas-bawangmerah-2013 pada tanggal 5 Maret 2017

[13] Kementerian Pertanian. Outlook Bawang Merah 2015. Diambil dari http://epublikasi.setjen.pertanian.go.id/arsipoutlook/76-outlook-hortikultura/356outlook-bawang-merah-2015 pada tanggal 5 Maret 2017

[14] Kementerian Pertanian. Outlook Bawang Merah 2016. Diambil dari http://epublikasi.setjen.pertanian.go.id/arsipoutlook/76-outlook-hortikultura/426outlook-bawang-merah-2016 pada tanggal 5 Maret 2017

[15] Suwandi, Adi, dkk.. Peramalan Data Time Series Dengan Metode Penghalusan Eksponensial Holt-Winter. Jurnal Universitas Hassanudin, Makasar. 2014. 